\title{
Diyarbakır ilinde mısır üreticilerinin bilgi kaynakları ve pazarlama sorunlarının incelenmesi
}

\section{An investigation of information sources and marketing problems of maize producers in Diyarbakır province}

\author{
Süleyman YAŞA ${ }^{1}$ (i), İlkay KUTLAR ${ }^{2}$ (i) \\ ${ }^{1}$ Akdeniz Üniversitesi, Fen Bilimleri Enstitüsü, Tarım Ekonomisi Anabilim Dalı, 07059, Antalya \\ ${ }^{2}$ Akdeniz Üniversitesi, Ziraat Fakültesi, Tarım Ekonomisi Bölümü, 07059, Antalya \\ Sorumlu yazar (Corresponding author): İ. Kutlar, e-posta (e-mail): ikutlar@akdeniz.edu.tr \\ Yazar(lar) e-posta (Author e-mail): slymnyasa07@gmail.com
}

MAKALE BİLGİSİ

Alınıș tarihi 13 Mayıs 2019

Düzeltilme tarihi 05 Temmuz 2019

Kabul tarihi 11 Temmuz 2019

\section{Anahtar Kelimeler:}

Bilgi kaynakları

Misir

Pazarlama

Diyarbakır

\begin{abstract}
$\ddot{0 ̈ z}$
Türkiye'de mısır tarımı Akdeniz, Güneydoğu Anadolu ve Batı Anadolu Bölgeleri’nde yaygın olarak yapılmaktadır. Türkiye'de mısır üretiminin \%15.8'ini Adana, \%11.3'ünü Mardin, \%10.7'sini Şanlıurfa ve \%8.7'sini Konya illeri karşılamaktadır. Diyarbakır ili ise Türkiye mısır üretiminin \%5.3'ünü karşılayarak 7. sırada yer almaktadır. Araștırma alanı olarak Diyarbakır ilinde en fazla mısır üretiminin yapıldığı Bismil ve Silvan ilçeleri seçilmiştir. Bu ilçelerde toplam 10 köyde 106 üretici ile yüz yüze anket yapılmıștır. Bu çalıșma mısır üreticilerinin sosyo-ekonomik durumlarını, mısır tarımı ile ilgili üretim tekniği ve ekonomik konulardaki bilgi kaynaklarını belirlemek amacıyla yapılmıştır. Ayrıca ilde mısırın pazarlama yapısı ve sorunları ortaya konulmuştur. İșletme genişlik gruplarına göre üreticilerin anket sorularına verdikleri cevaplar ki-kare testi ile analiz edilmiştir. Buna göre üreticilerin mısır tarımı hakkında ilk bilgi kaynakları ile ișletme genișlik grupları arasında ilișki olduğu tespit edilmiştir. Ayrıca işletme genişlik grupları ile pazarlama kanalları arasında da ilişki olduğu ortaya konulmuştur
\end{abstract}

\section{ARTICLE INFO}

Received 13 May 2019

Received in revised form 05 July 2019

Accepted 11 July 2019

\section{Keywords:}

Information source

Maize

Marketing

Diyarbakır

\begin{abstract}
Maize is cultivated in a large area in the Mediterranean Region of Turkey, followed by the Southeastern Anatolia and Western Anatolia regions. The pioneer provinces of maize production in Turkey are Adana (15.8\%), Mardin (11.3\%), Şanlıurfa $(10.7 \%)$ and Konya $(8.7 \%)$ respectively. Diyarbakir province is in the 7 th place, contributing $5.3 \%$ of country's total maize production. Bismil and Silvan districts of Diyarbakir province were selected as the research area for this study. Data were collected by administering a questionnaire to 106 maize producers operating in 10 villages. This study was conducted to determine the socio-economic status of maize producers, production techniques and sources of economic information about maize agriculture. Additionally, marketing structure of maize in the study area and problems are revealed. Data collected from respondents were analyzed using Chi-square test according to the size of landholding. Results showed that there was a significant relationship between producers' first agriculture information source and landholding size. Similarly, findings revealed a relationship between landholding size and marketing channels.
\end{abstract}

\section{Giriș}

Mısır bitkisi, orijini ve gen merkezi Amerika olan kültür bitkilerinin en önemlilerinden biridir. Bilinen yazılı kaynaklara göre mısır, Türkiye'ye Mısır'dan 1600 yılında getirilmiştir. Mısır içerdiği besin maddeleri bakımından hem insan hem de hayvan beslenmesinde önemli bir yere sahiptir. Misır endüstriyel tarım uygulamalarının stratejik ürünlerinden biri olduğu gibi endüstriyel gıda üretiminin temel hammaddelerinden biridir. Mısır unu, mısır nişastası, nişasta bazlı şeker, mısır yağı gibi çeşitli kullanım şekilleri yanında, bu kullanım şekillerinin elde edilmesi ya da etanol üretimi amacıyla işlendiğinde geriye kalan artıkları önemli bir yem kaynağıdır. Mısırdan ayrıca tüm yeşil aksamı kullanılarak yapılan silaj da hayvan beslenmesinde aranan bir kaba yemdir. Ayrıca kâğıt ve küçük çapta hasır el işleri yapımında da kullanılmaktadır. $\mathrm{Bu}$ kullanım alanlarının yanı sıra çerezlik olarak da tüketilmektedir (Elçi ve ark. 1987). Birleşmiş 
Milletler Gıda ve Tarım Örgütü (FAO) verilerine göre, dünyada toplam 1.5 milyar hektar tarım alanının yaklaşık 712 milyon hektarında tahıl ekimi yapılırken, bu alanın 183 milyon hektarında mısır yetiştirilmektedir. Dünya da 2.7 milyar ton tahıl üretimi içinde, mısır üretim miktarı 1.4 milyar tondur. En fazla misır üreten ülkeler ABD, Çin, Brezilya, Arjantin, Meksika, Hindistan, Ukrayna ve Endonezya 'dır. Türkiye dünyada misır üretiminde 24. sirada gelmektedir (FAO 2015). Mısır, Türkiye'de tahıllar içinde buğday ve arpadan sonra en geniş ekim alanına sahiptir. Mısır ekimi için iklim şartları bakımından en elverişli bölge Karadeniz Bölgesi'dir. Ancak bölgede çay ve findık gibi daha fazla gelir getiren kültür bitkilerinin yetiştirilmesi ve bölgenin topografik yapısı mısır ekim alanlarının daha fazla genişlemesine imkân vermemiştir (Taşdan ve Emeksiz 2003). Türkiye'de mısır ekim alanlarının en fazla olduğu bölge Akdeniz Bölgesi olup, bunu Güneydoğu Anadolu ve Batı Anadolu Bölgeleri takip etmektedir. Türkiye'de son 10 yıl içinde mısır ekim alanı 1.3 kat artmıştır. Diyarbakır ilinde ise mısır ekim alanı 6.2 kat artmıştır (TÜiK 2017). Bu artışta Diyarbakır ilinin mısır tarımı için uygun iklim koşullarına sahip olmasının yanı sıra Güneydoğu Anadolu Projesi'nin (GAP) de etkili olduğu söylenebilir. Türkiye'de mısır verimi ortalama $941 \mathrm{~kg} \mathrm{da}^{-1}$ dir. Diyarbakır ilinde ise mısır verimi ortalama $1126 \mathrm{~kg} \mathrm{da}^{-1}$, araştırma alanında ise 1400 $\mathrm{kg} \mathrm{da}^{-1}$ olarak tespit edilmiştir. Bu nedenle araştırma alanı olarak Diyarbakır ili seçilmiştir. Araştırmanın amacı; Diyarbakır ili Bismil ve Silvan ilçelerinde mısır tarımı ile uğraşan üreticilerden anket yoluyla elde edilen bilgiler 1şı̆̆ında, üreticilerin bilgi kaynaklarını ve pazarlama sorunlarını ortaya koymak ve önerilerde bulunmaktır.

\section{Materyal ve Yöntem}

Diyarbakır ilinde toplam misır üretiminin \%74.4'ü karşılayan Bismil ve Silvan ilçeleri araştırma alanı olarak belirlenmiştir (Anonim 2017). Araştırmanın ana materyalini Bismil ilçesinde Ambar, Çöltepe, Tepe, Üçtepe, Köseli ve Silvan ilçesinde ise Çevriksu, Çiğil, Güzderesi, Kıraçtepe ve Yeşerdi olmak üzere toplam 10 köydeki üreticilerden anket yoluyla elde edilen birincil veriler oluşturmuştur. Köylerin belirlenmesinde Tarım ve Orman ilçe Müdürlüklerinin Çiftçi Kayıt Sistemi (ÇKS) verilerinden ve teknik personelin görüş ve tecrübelerinden yararlanılmıştır. Ayrıca konu ile ilgili daha önce yapılan araştırmalar, istatistikler ve çalışmalardan da yararlanılmıştır.

Örnek hacminin belirlenebilmesi için popülasyonu oluşturan işletmelerin ekilen arazi varlığını gösteren frekans tablosu düzenlenmiştir. Daha sonra işletmeler frekans eğrisi yardımıyla 1-100 dekar, 101-250 dekar ve 251 ve üzeri dekar olmak üzere 3 tabakaya ayrılmıştır. Dağılım bu tabakalar içinde normal dağılım eğrisine yakın görüldüğünden, böyle bir tabakalama yapılması uygun görülmüştür. ÇKS verilerine göre araştırma alanı olarak tespit edilen 10 köyde toplam 609 işletme bulunmaktadır. Popülasyonu temsil edecek uygun örnek hacmi, tabakalı tesadüfi örnekleme yöntemine göre Neyman Eşitliği (Çiçek ve Erkan 1996; Yamane 2001) kullanılarak tespit edilmiştir. Örnek hacminin hesaplanmasında hata payı ortalama ekilen arazi varlığının \%5'i kabul edilmiş ve \%95 güvenirlik sınırları içinde çalışılmıştır. Buna göre örnek hacmi 106 işletme olarak belirlenmiştir.

Her tabakadan örneğe girecek işletmelerin tespitinde tabakaların varyansları esas alınmış ve "Tabaka Varyansına Göre Paylaştırma Yöntemi” kullanılmıştır. $\mathrm{Bu}$ yöntemde tabakalardaki birim sayıları ve standart sapmalar dikkate alınarak, her tabakadan alınacak örnek büyüklügü hesaplamıştır (Çiçek ve Erkan 1996). Buna göre; 100 dekardan küçük araziye sahip I. tabakadan 31 adet, 101-250 dekar araziye sahip II. tabakadan 34 adet ve 251 dekar ve üzeri araziye sahip III. tabakadan 41 adet olmak üzere toplam 106 üretici ile anket yapılmıştır.

Anket uygulaması sonucu elde edilen veriler istatistik paket programında değerlendirilmiştir. Buna göre işletmeler; işletme genişlikleri, aile genişliği, yaş grupları, eğitim durumu, mısır üretiminde bilgi kaynakları, pazarlama kanalları gibi bazı özelliklerine göre gruplandırılmıştır. Araştırma sonuçlarının analizinde misır üreticilerinin sorulara verdikleri yanitlar ile oluşturulan arazi genişlik grupları arasındaki olası istatistiki ilişki ki-kare analizi ile test edilmiştir (Kesici ve Kocabaş 1998).

\section{Bulgular}

\section{1. Üreticilerin sosyo-ekonomik özellikleri}

Türkiye'de tarımsal üretim aile işgücüne dayanır. Tarımsal üretimde bulunan işletmelerin nüfus varlığının bilinmesi, işletmelerin sahip olduğu işgücünün belirlenmesi ve işgücünün etkin değerlendirilmesi bakımından önem taşımaktadır. Ayrıca bir üretim faktörü olan işgücünün sosyal ve ekonomik özelliklerinin incelenmesi insan kaynağının geliştirilmesine yönelik çalışmalara veri oluşturması bakımından da önemlidir (Özkan 2000).

TÜİK hane halkı tanımı; aralarında akrabalık bağı bulunsun ya da bulunmasin ayn1 konutta veya ayn1 konutun bir bölümünde yaşayan, temel ihtiyaçlarını birlikte karşılayan, hane halk1 hizmet ve yönetimine iştirak eden bir veya birden fazla kişiden oluşan topluluktur. Türkiye'de ortalama aile genişliği 3.4 kişidir. İncelenen işletmelerde aile genişlikleri en az 2 kişi iken, en fazla 14 kişi ve ortalama aile genişliği ise 5.83 kişi olduğu belirlenmiştir. Türkiye İstatistik Kurumu verilerine göre Diyarbakır ilinde ortalama hane halkı büyüklügü 5 kişi olarak verilmiştir (TÜİK 2017). Araştırmanın kırsal alanda yapılması nedeniyle ortalama aile genişliğinin yüksek çıkması beklenen bir durumdur. Antalya ilinde mısır üreticilerine yönelik yapılan bir çalışmada ortalama aile genişliği 4.53 kişi olarak bulunmuştur (Özçatalbaş ve ark. 2002).

Tarımsal üretim faaliyetlerinin yürütülmesinde üretici tutum ve davranışlarında, yaş ve eğitim önemli bir faktördür (Özçatalbaş ve Gürgen 1998). Araştırma alanında üreticilerin ortalama yaşı 44.72 'dir. Antalya ilinde mısır üreticilerine yönelik yapılan bir çalışmada üreticilerin ortalama yaşı 44.69 olarak bulunmuştur (Özçatalbaş ve ark. 2002). Araştırma alanında üreticiler 40 yaş ve altı (\%39.6), 41 yaş ve üzeri (\%60.4) şeklinde 2 gruba ayrılmıştır. İşletme genişlik grupları ile üreticilerin yaş grupları arasında anlamlı bir ilişki olmadığ ki-kare analizi ile saptanmıştır (Çizelge 1).

İncelenen işletmelerde üreticilerin çiftçilik deneyimi en az 1 y1l iken en fazla 32 y1l ve ortalama 5.62 yıldır. Antalya ilinde mısır üreticilerine yönelik yapılan bir çalışmada üreticilerin ortalama çiftçilik deneyimi 5.64 yıl olarak bulunmuştur (Özçatalbaş ve ark. 2002). Araştırmada üreticilerin \%67.9'unun misır üretiminde 5 yildan az, \%32.1'inin ise 5 yıldan fazla deneyime sahip olduğu belirlenmiştir.

Eğitim düzeyi üretici davranışlarını etkileyen bir faktör olarak ele alınmakta ve hemen her anlamda birey davranışlarını olumlu yönde değiştirmenin en önemli aracı olarak düşünülmektedir. Eğitim düzeyi; gelişmeleri takip etme, gerekli kaynaklara ulaşma, ilgili kuruluşlarla iletişim kurma, üretim 
faaliyetinde karar verme ve uygulama gibi birçok durumda en önemli etkenlerden biri olmaktadır (Oruç 2001). Eğitim düzeyi kırsal alanda yaşayanların sosyo-ekonomik düzeylerini göstermesi açısından da önemli bir özelliktir. Ancak yapılan çalışmalar, tarım sektöründe okuma yazma oranının diğer sektörlere göre daha düşük olduğunu göstermektedir (Özçatalbaş ve Gürgen 1998).

Araştırmada üreticilerin eğitim durumu resmi eğitim almamış (okuryazar olmayan veya okuryazar), ilköğretim (ilkokul veya ortaokul mezunu), ortaögretim ve üzeri (lise veya yükseköğretim mezunu) olmak üzere üç gruba ayrılmıştır. Buna göre üreticilerin \%18.9'u resmi eğitim almamış, \%50.0'si ilköğretim mezunu ve \%31.1'i ise ortaöğretim ve üzeri eğitim düzeyine sahip olduğu tespit edilmiştir (Çizelge 2). Çukurova bölgesinde mısır üreticilerine yönelik yapılan bir çalışmada üreticilerin \%45.71'i ilkokul, \%22.86's1 ortaokul, \%28.57'si lise ve geriye kalan \%2.86's1 üniversite mezunu olduğu belirlenmiştir (Alemdar ve ark. 2014). Araştırmada işletme genişlik grupları ile üreticilerin eğitim düzeyi arasında anlamlı bir ilişki olmadığı ki-kare analizi ile saptanmıştır (Çizelge 2).

Araştırmada üreticilerin \%87.7'si gelirinin tamamını tarımsal faaliyetlerden, \%12.3'ü ise hem tarım, hem de tarım dışı faaliyetlerden sağlamaktadır. Üreticilerin gelir kaynaklarının \%64.1'ini mısır üretimi, \%8.5'ini bitkisel ve hayvansal üretim ve \%27.4'ünü ise mısır üretimi ve tarım dış1 gelir oluşturmaktadır.

İncelenen işletmelerde üreticilerin \%36.8'i tarımsal amaçlı bir kooperatife ortak iken \%63.2'si değildir. Üreticilerin $\% 41.5$ ' $\mathrm{i}$ tarım sigortas1 yaptırırken, \%58.5' $\mathrm{i}$ ise yaptırmamaktadır. Tarım sigortası yaptıran üreticilerin $\% 70.5$ ' $\mathrm{i}$ afete karş1 yaptırdığını, \%29.5'i ise kredi başvurularında tarım sigortası yaptırma şartı olduğu için yaptırdıklarını ifade etmiştir. Tarım sigortası yaptırmayan üreticilerin $\% 41.9$ 'u ürün maliyetini artırdığı, \%37.1'i mısır tarımını riskli görmediği ve \%21.0'i ise primleri yüksek bulduğu için tarım sigortasını yaptırmadığını belirtmiştir.

\section{2. İsletmelerin Genel Özellikleri}

Türkiye'de tarım arazileri; miras, sermaye ve işgücü yetersizliğinden dolayı kiracılık ve ortakçılık, çeşitli

Çizelge 1. Üreticilerin yaş gruplarına göre dağılımı.

Table 1. Distribution of generators by age groups.

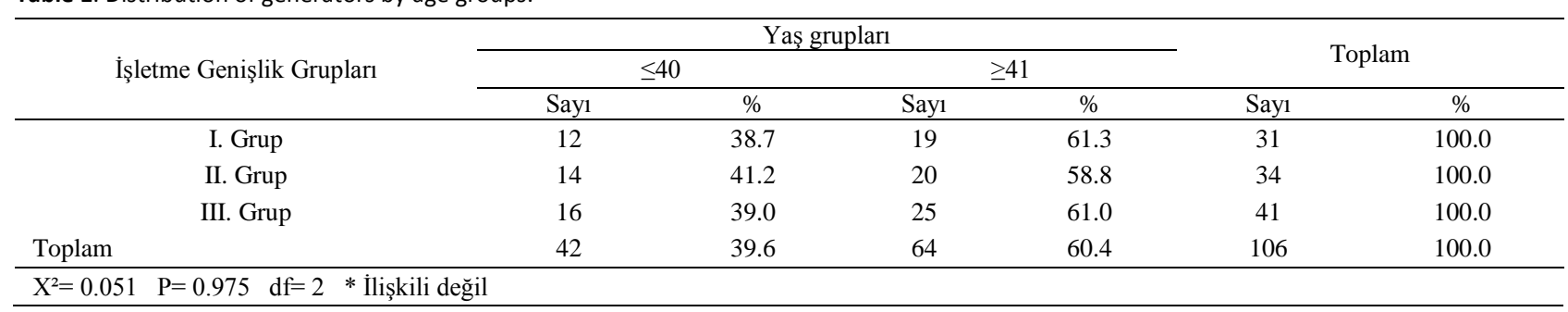

Çizelge 2.Üreticilerin eğitim durumu.

Table 2. Educational status of producers.

\begin{tabular}{|c|c|c|c|c|c|c|c|c|}
\hline \multirow{2}{*}{ İşletme Genişlik Grupları } & \multicolumn{2}{|c|}{ Resmi eğitim almamış } & \multicolumn{2}{|c|}{ İlköğretim } & \multicolumn{2}{|c|}{ Ortaöğretim ve üzeri } & \multicolumn{2}{|c|}{ Toplam } \\
\hline & Say1 & $\%$ & Say1 & $\%$ & Say1 & $\%$ & Sayı & $\%$ \\
\hline I.Grup & 6 & 19.4 & 15 & 48.3 & 10 & 32.2 & 31 & 100.0 \\
\hline II.Grup & 11 & 32.4 & 14 & 41.2 & 9 & 26.4 & 34 & 100.0 \\
\hline III.Grup & 3 & 7.3 & 24 & 58.6 & 14 & 34.1 & 41 & 100.0 \\
\hline Toplam & 20 & 18.9 & 53 & 50.0 & 33 & 31.1 & 106 & 100.0 \\
\hline
\end{tabular}

$\mathrm{X}^{2}=7.693 \quad \mathrm{P}=0.104 \quad \mathrm{df}=4 \quad *$ İlişkili değil kamulaştırmalar, arazi alım-satım işleri gibi nedenlerle parçalanmaktadır. Bu nedenlerden dolayı işletmelerin işledikleri arazi miktarları küçülmekte ve işletmeler birbirlerinden uzak, çok sayıda ve düzensiz parçalardan oluşmaktadır. Türkiye'de \%78.9'u 100 dekardan küçük işletme genişlik gruplarında yer almaktadır. Bu işletmelerin tasarrufunda bulundurduğu arazi ise toplam arazinin \%34.3'ünü oluşturmaktadır (Yücer ve ark. 2015). İncelenen işletmeler en az 2 dekar, en fazla 800 dekar ve ortalama 222.81 dekar olup üreticilerin $\% 69.8$ 'i yalnız kendi, \%16.0's1 kira ve \%14.2'si ise ortakçılık ile arazi işleten konumundadır. Araştırmada 30 işletmenin, mısır dışında başka ürünlerde (\%63.3'ü buğday, \%20.0'si kırmızı mercimek ve \%16.7'si ise pamuk) ürettiği tespit edilmiştir. Çukurova bölgesinde misır üreticilerine yönelik yapılan bir çalışmada işletmelerde toplam arazi içerisinde $\% 74.5$ ' $\mathrm{i}$ yalnız kendi arazisini işleten, \%24.9'u kira ile arazi işleten ve \%0.6's1 ise ortakçıllk ile arazi ișleten olduğu belirlenmiștir (Alemdar ve ark. 2014). Araştırma alanında üreticilerin süt ve süt ürünleri ve diğer hayvancilıktan elde ettikleri ürünleri aile içinde tükettikleri, pazarlamadıkları görülmüştür. İncelenen işletmeler traktör, pulluk, gübre makinesi, çapa, tapan, mibzer gibi bitkisel üretim faaliyetlerinde kullanılan tarımsal alet ve makinaların tamamina sahiptir. mısır tarımını işçiliğinin az, bakımının kolay, fiyatının ve veriminin yüksek olmasından dolayı tercih ettikleri belirlenmiştir. Adana ili Yüreğir ilçesinde ana ürün mısır üretimi yapan üreticilere yönelik bir çalışmada, işletmelerin $\% 32.1$ 'i mısırda zirai ilaç kullanılmaması, \%25.0'i ürünün işçiliğinin az ve bakımının kolay olması, \%21.4'ü mısırda erken hasadın olması ve \%2.4'ü ise depolama imkanı olması gibi nedenlerden dolayı mısır tarımının tercih edildiği belirlenmiştir (Gül 1998). toplam işletme sayısı 3022 127'dir. Tarımsal işletmelerin

Elde edilen verilere göre araştırma alanında üreticilerin verimin yüksek olması, \%10.7'si ekim nöbetinin olması \%8.3'ü 


\section{3. Üreticilerin Bilgi Kaynaklart}

Bilgi; öğrenme, araştırma ve gözlem yolu ile elde edilen gerçektir. Tarımsal bilgi; toprak, işgücü, sermaye ve girişimcilik gibi önemli bir tarımsal üretim faktörüdür (Demiryürek 2010). Ayrıca tarımsal bilgi üreticiler için toprak, su, tohum gibi son derece önemli bir kaynaktır. Çünkü üreticilerin bitkisel ve hayvansal üretim faaliyetleri ile ilgili teknik veya ekonomik konularda bilgiye sahip olmadan, ellerindeki kaynakları verimli ve etkin bir șekilde kullanmaları oldukça güçür. Kırsal alana ulaşan bilgiler, kırsal toplum içinde yaratılabileceği gibi kırsal toplum dışında da yaratılabilir (Soysal 1998). Yapılan araştırmalar üreticilerin ihtiyaç duydukları konularda geleneksel ve modern bilgi kaynaklarından yararlandıklarını göstermektedir (Özçatalbaş ve Ünlü 2018; Torun 2011; Boz 2002; Boz ve Özçatalbaş 2010; Yılmaz ve ark. 2009; Yalçın ve Boz 2007; Boz ve ark. 2004). Geleneksel bilgi, kırsal alanda yaratılan, üretici ve aile bireylerinin yanında akraba ve diğer üreticiler tarafından kullanılan, tarımsal faaliyetlerde yaşadıkları sorunları çözmek üzere üretilmiş, denenmiş ve doğruluğu test edilmiş bilgidir. Modern bilgi ise üniversiteler ve diğer araştırma kuruluşları tarafından geliştirilen yeni teknik ve teknolojilerdir. Geleneksel bilgi kaynakları üreticinin kendi bilgi ve tecrübesi, aile bireyleri, akraba ve diğer üreticilerdir. Modern bilgi kaynakları ise üreticileri tarımsal yeniliklerden haberdar eden il/ilçe tarım müdürlüklerinde çalışan tarım yayımcıları ve sivil toplum örgütlerinde, ziraat odalarında ve tarımsal danışmanlık şirketlerinde istihdam edilen veya tarımsal danışmanlık hizmeti yürütmek üzere kendi nam ve hesabına çalışan tarım danışmanlarıdır. Bunun yanında tarıma girdi sağlayan tohum, gübre ve ilaç bayileri de üreticilerin başvurduğu diğer modern bilgi kaynakları arasında yer almaktadır (Boz ve ark. 2004).

İncelenen işletmelerde üreticilerin mısır üretiminde ilk bilgi kaynağının \%56.6'sını geleneksel bilgi ve \%43.4'ünü ise modern bilgi oluşturmaktadır. Araştırmada işletme genişlik grupları ile üreticilerin mısır üretimi hakkında ilk bilgi kaynakları arasında anlamlı bir ilişki olduğu ki-kare analizi ile saptanmıştır (Çizelge 3). Diğer bir deyişle küçük işletmeler mısır üretimi ile ilgili ilk bilgi kaynağı olarak geleneksel bilgi kaynaklarından yararlanırken, büyük işletmeler ise modern bilgi kaynaklarından yararlanmaktadır.

Çizelge 4'de üreticilerin şuanda mısır üretimi ile ilgili teknik ve ekonomik konularda yararlandıkları bilgi kaynakları verilmiştir. Buna göre teknik konularda üreticilerin \%35.1'i geleneksel bilgi kaynaklarından ve \%69.4'ü ise modern bilgi kaynaklarından yararlanırken; ekonomik konularda üreticilerin $\% 37.5$ 'i geleneksel bilgi kaynaklarından ve $\% 62.5$ 'i ise modern bilgi kaynaklarından yararlanmaktadır. Elde edilen verilere göre üreticilerin teknik ve ekonomik konularda yararlandıkları bilgi kaynakları arasında anlamlı bir ilişki olmadığı ki-kare analizi ile saptanmıştır. Kısaca üreticilerin mısır üretimi ile ilk bilgi kaynağ1 olarak geleneksel (\%56.6) bilgi kaynaklarından, şuan da ise modern (\%63.2) bilgi kaynaklarından yararlandıkları görülmektedir (Çizelge 4).

\subsubsection{Teknik Konularda Bilgi Kaynakları}

Gaziantep ilinde yapılan bir çalışmada üreticilerin hastalık ve zararlılarla mücadelede modern bilgi kaynaklarını tercih ettiği (\%67.46), tarımsal üretimin diğer aşamalarında ise geleneksel bilgi kaynaklarından yararlandıkları belirtilmiştir. Çalışmada üreticilerin sulama uygulaması (\%73.97), toprak hazırlı̆̆ $(\% 68.64)$, hasat ve depolama (\%65.08), tohumluk seçimi ve ekim (\%57.98), gübre seçimi ve gübreleme $(\% 56.21)$ gibi üretim aşamalarında geleneksel bilgi kaynaklarını tercih ettiği tespit edilmiştir. Üreticilerin pazarlama $(\% 58.58)$ ve girdi seçimi (\%53.85) gibi ekonomik konularda da geleneksel bilgi kaynaklarına başvurdukları belirlenmiştir (Boz ve Özçatalbaş 2010).

Araştırma alanında üreticilere mısır üretimi ile ilgili teknik konularda yararlandıkları bilgi kaynakları her bir üretim aşaması için ayrı ayrı sorulmuştur. Buna göre tohum seçiminde üreticilerin $\% 58.5$ 'i geleneksel ve $\% 41.5$ 'i ise modern; misır ekim tekniği ile ilgili konularda \%65.1'i geleneksel ve \%34.9'u modern; sulama sayısın $\% 35.8$ 'i modern; gübre seçimi, gübreleme zamanı ve uygulamas1 gibi konularda $\% 42.5$ ' $\mathrm{i}$ geleneksel ve $\% 57.5$ ' $\mathrm{i}$ ise modern; hastalı ve zararlllarla mücadelede ise $\% 32.1$ ' $\mathrm{i}$ geleneksel ve \%67.9'u modern bilgi kaynaklarından yararlanmaktadır (Çizelge 5).

Çizelge 3. Üreticilerin ilk bilgi kaynakları.

Table 3. The first information sources of producers.

\begin{tabular}{|c|c|c|c|c|c|c|}
\hline \multirow{3}{*}{ İşletme Genişlik Grupları } & \multicolumn{4}{|c|}{ Bilgi kaynakları } & \multirow{2}{*}{\multicolumn{2}{|c|}{ Toplam }} \\
\hline & \multicolumn{2}{|c|}{ Geleneksel } & \multicolumn{2}{|c|}{ Modern } & & \\
\hline & Say1 & $\%$ & Say1 & $\%$ & Say1 & $\%$ \\
\hline I. Grup & 23 & 74.2 & 8 & 25.8 & 31 & 100.0 \\
\hline II. Grup & 21 & 61.8 & 13 & 38.2 & 34 & 100.0 \\
\hline III. Grup & 16 & 39.0 & 25 & 61.0 & 41 & 100.0 \\
\hline Toplam & 60 & 56.6 & 46 & 43.4 & 106 & 100.0 \\
\hline
\end{tabular}

Çizelge 4. Üreticilerin teknik ve ekonomik konularda yararlandıkları bilgi kaynakları.

Table 4. Information sources used by producers in technical and economic matters.

\begin{tabular}{|c|c|c|c|c|c|c|}
\hline \multirow{3}{*}{ Konular } & \multicolumn{4}{|c|}{ Bilgi kaynakları } & \multirow{2}{*}{\multicolumn{2}{|c|}{ Toplam }} \\
\hline & \multicolumn{2}{|c|}{ Geleneksel } & \multicolumn{2}{|c|}{ Modern } & & \\
\hline & Say1 & $\%$ & Say1 & $\%$ & Say1 & $\%$ \\
\hline Teknik & 12 & 35.1 & 22 & 64.9 & 34 & 100.0 \\
\hline Ekonomik & 27 & 37.5 & 45 & 62.5 & 72 & 100.0 \\
\hline Toplam & 39 & 36.8 & 67 & 63.2 & 106 & 100.0 \\
\hline
\end{tabular}




\subsubsection{Ekonomik konularda bilgi kaynakları}

Araştırma alanında mısır üreticilerinin mısır piyasası (fiyatı) hakkında bilgi kaynağı olarak; tüccarlar (\%42.5), TMO (\%32.1), diğer üreticiler (\%14.2) ve internetten (\%11.2) yararlandıkları belirlenmiştir. İşletme genişlik grupları ile üreticilerin mısır piyasası (fiyat) hakkında bilgi kaynakları arasında anlamlı bir ilişki olmadığı ki-kare analizi ile saptanmıştır (Çizelge 6).

Aşağı Seyhan Sulama Projesi alanında yapılan bir çalışmada mısır satış fiyatları ve koşullarının öğrenilmesinde tüccarlar (\%66.7) ve TMO'nun (\%20.3) en önemli bilgi kaynakları olduğu tespit edilmiştir (Özçatalbaş ve Gürgen 1992).

\subsection{Pazarlama yapısl ve sorunlar}

Tarım ürünlerinin pazarlanması üretilen ürünlerin tarla, bahçe ya da tarımsal işletme gibi üretim merkezlerinden tüketiciye ulaşıncaya kadar geçen her aşamadaki faaliyetleri kapsamaktadır. Tarım ürünlerinde pazarlama sistemleri, ürünün yapısına göre farklılık göstermektedir. Örneğin tahıl ürünlerinin pazarlanmasında en önemli aktörler; Toprak Mahsulleri Ofisi (TMO), ticaret borsaları, tüccarlar, yem fabrikaları ve diğer sanayi kuruluşlarıdır (Albayrak ve ark. 2010).

Araştırma alanında üreticilerin \%44.3'ü TMO'ne, \%40.6'sı tüccara ve $\% 15.1$ 'i ise yem fabrikalarına ürettikleri misırı pazarlamaktadır. İşletme genişlik grupları ile üreticilerin mısır pazarlama kanalları arasında anlamlı bir ilişki olduğu ki-kare analizi ile saptanmıştır (Çizelge 7).

Özellikle işletme genişlik grupları açısından II. ve III.Grup üreticiler, TMO ile protokol imzalayan lisanslı depolara ürün teslim edebilecek maddi imkanı olması nedeniyle pazarlama kanalı olarak TMO'ni tercih ederken, I.Grup üreticiler ise maddi imkanları yetersiz olduğu için mısırın nem oranı artmadan biran önce tüccara satmayı tercih etmektedirler. Çünkü TMO, mısır alım fiyatını nem oranına göre belirlemekte ve randevu ile ürün kabul etmektedir. Yani üreticiler misırı hasat eder etmez TMO'ne götürememekte, randevu gününün gelmesini beklemektedir. $\mathrm{Bu}$ durumda da misır bitkisi, özelliği gereği kurutulup depolanmadığ 1 için nem oranı artmakta, bu da mısırın alım fiyatının düşmesine neden olmaktadır. Kısacası üreticilerin \%42.5'i mısırın piyasa fiyatı hakkında bilgi kaynağı olarak tüccarlardan yararlanmakta, piyasanın durumuna göre mısırını tüccara veya TMO'ne satmaya karar vermektedir.

TMO'nun verilerine göre 2016 yılında Türkiye'de üretilen toplam mısırın \%27.5'i TMO tarafından alınmıştır (TMO 2017). Araştırma alanında da üreticilerin misır pazarlamasında yaşadıkları en önemli sorunlar; pazarlama kanallarının azlığ (\%9.4) ve TMO'daki prosedürler (\%3.8) olarak tespit edilmiştir. $\mathrm{Bu}$ nedenle üreticilerin mısır için yeni pazarlama kanalları bulması önemlidir.

Çizelge 5. Üreticilerin teknik konularda yararlandıkları bilgi kaynakları.

Table 5. Information sources used by producers in technical matters.

\begin{tabular}{|c|c|c|c|c|c|c|}
\hline \multirow{3}{*}{ Teknik konular } & \multicolumn{4}{|c|}{ Bilgi kaynakları } & \multirow{2}{*}{\multicolumn{2}{|c|}{ Toplam }} \\
\hline & \multicolumn{2}{|c|}{ Geleneksel } & \multicolumn{2}{|c|}{ Modern } & & \\
\hline & Say1 & $\%$ & Say1 & $\%$ & Say1 & $\%$ \\
\hline Tohum seçimi & 62 & 58.5 & 44 & 41.5 & 106 & 100.0 \\
\hline Ekim tekniği & 69 & 65.1 & 37 & 34.9 & 106 & 100.0 \\
\hline Sulama sayısı & 68 & 64.2 & 38 & 35.8 & 106 & 100.0 \\
\hline Gübre seçimi & 45 & 42.5 & 61 & 57.5 & 106 & 100.0 \\
\hline Hastalık ve zararlılarla mücadele & 34 & 32.1 & 72 & 67.9 & 106 & 100.0 \\
\hline
\end{tabular}

Çizelge 6. Üreticilerin mısır piyasası (fiyatı) hakkında bilgi kaynakları.

Table 6. Sources of information on producers' maize market (price).

\begin{tabular}{|c|c|c|c|c|c|c|c|c|}
\hline \multirow{3}{*}{$\begin{array}{c}\text { Misır piyasası (fiyat) } \\
\text { hakkında bilgi kaynakları }\end{array}$} & \multicolumn{6}{|c|}{ İşletme genişlik grupları } & \multirow{2}{*}{\multicolumn{2}{|c|}{ Toplam }} \\
\hline & \multicolumn{2}{|c|}{ I.Grup } & \multicolumn{2}{|c|}{ II.Grup } & \multicolumn{2}{|c|}{ III.Grup } & & \\
\hline & Sayı & $\%$ & Sayı & $\%$ & Sayı & $\%$ & Sayı & $\%$ \\
\hline Tüccarlar & 15 & 48.3 & 11 & 32.2 & 19 & 46.4 & 45 & 42.5 \\
\hline TMO & 12 & 38.7 & 14 & 41.2 & 8 & 19.5 & 34 & 32.1 \\
\hline Diğer üreticiler & 2 & 6.5 & 5 & 14.7 & 8 & 19.5 & 15 & 14.2 \\
\hline İnternet & 2 & 6.5 & 4 & 11.8 & 6 & 14.6 & 12 & 11.2 \\
\hline Toplam & 31 & 100.0 & 34 & 100.0 & 41 & 100.0 & 106 & 100.0 \\
\hline
\end{tabular}

Çizelge 7. Üreticilerin pazarlama kanalları.

Table 7. Marketing channels of producers.

\begin{tabular}{|c|c|c|c|c|c|c|c|c|}
\hline \multirow{3}{*}{ Pazarlama kanalları } & \multicolumn{6}{|c|}{ İşletme genişlik grupları } & \multirow{2}{*}{\multicolumn{2}{|c|}{ Toplam }} \\
\hline & \multicolumn{2}{|c|}{ I.Grup } & \multicolumn{2}{|c|}{ II.Grup } & \multicolumn{2}{|c|}{ III.Grup } & & \\
\hline & Sayı & $\%$ & Say1 & $\%$ & Say1 & $\%$ & Sayı & $\%$ \\
\hline TMO & 12 & 38.7 & 20 & 58.8 & 15 & 36.6 & 47 & 44.3 \\
\hline Tüccar & 17 & 54.8 & 12 & 35.3 & 14 & 34.1 & 43 & 40.6 \\
\hline Yem fabrikaları & 2 & 6.5 & 2 & 5.9 & 12 & 29.3 & 16 & 15.1 \\
\hline Toplam & 31 & 100.0 & 34 & 100.0 & 41 & 100.0 & 106 & 100.0 \\
\hline $\mathrm{X}^{2}=13.495 \quad \mathrm{P}=0.009 \quad \mathrm{df}=4$ & * İlişskili & & & & & & & \\
\hline
\end{tabular}




\section{Sonuç}

Günümüzde teknolojide yaşanan gelişmeler tarım sektörünü de etkilemiş, tarımsal faaliyetin yeniden şekillenmesine yol açmıştır. Böylece ülkeler sahip oldukları tarımsal potansiyeli daha etkin kullanmak için yeni tarım tekniklerini ve teknolojilerini, tarımda kullanma yarışına girmiştir. Ancak tarım sektöründe yaşanan yeniliklerin her üreticiye aynı zamanda ulaşması ve üreticiler tarafindan da hemen benimsenmesi ve uygulanması aynı hızda olmamaktadır. Çünkü üreticilerin büyük çoğunluğu geleneksel yöntemlerle yani kendi bilgi ve tecrübeleri ile üretim yapmaktadır. Ancak herhangi bir sorunla karşılaştıkları zaman diğer üreticilere ya da modern bilgi kaynaklarına başvurmaktadır. Araştırma alanında mısır üreticilerinin bilgi kaynakları ve pazarlama sorunları incelenmiştir. Buna göre üreticiler mısır üretimi ile ilgili ilk bilgi kaynağı olarak geleneksel (önder çiftçi, komşu/akraba ve diğer üreticilerden), mevcut bilgi kaynağı olarak ise modern (il ve ilçe müdürlüklerindeki ziraat mühendisleri, zirai ilaç bayileri ve özel tarım danışmanlarından) bilgi kaynaklarından yararlanmaktadır. Piyasa fiyatı ve diğer ekonomik konularda ise bilgi kaynağı olarak TMO, tüccarlar, diğer üreticiler ve internetten yararlandıkları tespit edilmiştir. Üreticiler tohum seçimi, ekim tekniği ve sulama gibi konularda geleneksel bilgi kaynaklarından; gübreleme, hastalık ve zararlılarla mücadele gibi konularda ise modern bilgi kaynaklarından yararlanmaktadır.

$\mathrm{Bu}$ verilerden yola çıkarak il tarım ve orman müdürlüğü tarafindan üreticilerin ihtiyaç duyduğu gübreleme, hastalık ve zararlılarla mücadele gibi konularda eğitimler verilmesi yararlı olacaktır. Ayrıca üreticilere internet kullanımı, pazarlama ve eticaret gibi konularda da eğitimler verilebilir. Araştırma alanında üreticiler; fiyat oluşumunda söz sahibi olamama, devlet desteğinin az, pazarlama kanallarının yetersiz, TMO'nun ürün alım prosedürlerinin çok, kurutma ve depolama maliyetlerinin yüksek, lisanslı depo sayısının az olması gibi sorunlar yaşadıklarını ifade etmişlerdir. Ancak üreticiler kendi aralarında örgütlendiği ya da sözleşmeli tarım modelini benimsediği zaman bu sorunların çözülmesi mümkün olabilir. Bunun için araştırma alanındaki üreticilere, il tarım ve orman müdürlüğü tarafından örgütlenmenin önemi ve yararlarının anlatıldığ 1 toplantılar düzenlenmeli, tarımsal amaçlı kooperatif kurmaları teşvik edilmelidir. Böylece üreticiler, kooperatifler aracılığıyla üretimde kullandıkları girdileri düşük fiyatla alabilir, ürettikleri ürünleri ise yüksek fiyattan satabilirler. Hatta kurutma tesisleri ve lisanslı depolar kurarak ürünlerini muhafaza edebilirler. Kısacası tarımsal ürün piyasalarında daha güçlü yer alabilirler, tekelleşmeyi önleyebilirler.

\section{Kaynaklar}

Albayrak M, Taşdan K, Güneş E, Saner G, Atış E, Çukur F, Pezikoğlu, (2010) Küresel Rekabet Açısından Türkiye'de Tarım ve Gıda Ürünleri Pazarlama Sistemlerine Bakış: Mevcut Yapı, Sorunlar, Firsatlar, Hedefler. Türkiye Ziraat Mühendisliği VII. Teknik Kongresi, Ankara, s. 1305-1320.

Alemdar T, Seçer A, Demirdöğen A, Öztornacı B, Aykanat S (2014) Çukurova Bölgesinde Başlıca Tarla Ürünlerinin Üretim Maliyetleri ve Pazarlama Yapıları. Tarımsal Ekonomi ve Politika Geliştirme Enstitüsü, Tepge Yayın No: 230 ISBN: 978-605-4672-65-3.

Anonim (2017) Diyarbakır İl Tarım ve Orman Müdürlüğü kayıtlarından derlenmiştir, Diyarbakır.
Boz İ (2002) Does Early Adoption Affect Farmers' Use of the Extension Service?. Association for International Agricultural and Extension Education (AIAEE) 9(3): 77-82.

Boz İ, Akbay C, Orhan E, Candemir S (2004) Çiftçilerin Tarımsal Faaliyetlerde Kullandıkları Bilgi Kaynaklarının Belirlenmesi ve Tarımsal Yayım Açısından Değerlendirilmesi. VI. Tarım Ekonomisi Kongresi, Tokat.

Boz İ, Özçatalbaş O (2010) Determining Information Sources Used by Crop Producers:A Case Study of Gaziantep Province in Turkey. African Journal of Agricultural Research 5(10): 980-987.

Çiçek A, Erkan O (1996) Tarım Ekonomisinde Araştırma ve Örnekleme Yöntemleri. Gaziosmanpaşa Üniversitesi Ziraat Fakültesi Yayınları, No: 12, Ders Notları Serisi: 6, Tokat.

Demiryürek K (2010) Information Systems and Communication Networks for Agriculture and Rural People. Agric. Econ.-Czech 56(5): 209-214.

Elçi S, Kolsarıcı Ö, Geçit, H (1987) Tarla Bitkileri. A.Ü.Ziraat Fak.Yay No: 100, Ofset Basim: 30, Ankara.

FAO (2015) Food and Agriculture Organization of the United Nations, Compiled from FAOSTAT data.

Gül M (1998) Yüreğir İlçesinde Sulanan Alanlarda Misırda Üretim Maliyetleri ve Üretici Sorunları. Çukurova üniversitesi Fen Bilimleri Enstitüsü, Tarım Ekonomisi Ana Bilim Dalı Yüksek Lisans Tezi, Adana.

Kesici T, Kocabaş Z (1998) Biyoistatistik.Ankara Üniversitesi Eczacılık Fakültesi Yayın No: 79, Ankara, s. 182-185.

Oruç E (2001) Tokat İlinde Bitkisel Üretimde Tarımsal Mücadele Uygulamaları ve Çiftçilerin İlaç Kullanımı Konusundaki Bilgi Düzeyleri ile Bilgi Kaynakları Üzerine Araştırma. Ankara Üniversitesi Fen Bilimleri Enstitüsü, Tarım Ekonomisi Anabilim Dalı Doktora Tezi, Ankara.

Özçatalbaş O, Gürgen Y (1992) Aşağı Seyhan Sulama Proje Alanındaki Mısır Üreticilerinin Bilgi Edinme Kaynakları. Çukurova Üniversitesi Ziraat Fakültesi Dergisi 7/2: 63-78.

Özçatalbaş O, Gürgen Y (1998) Tarımsal Yayım ve Haberleşme. Baki Kitap Evi, Adana, s. 334.

Özçatalbaş O, Özkan B, Kutlar İ (2002) Antalya'da Mısır Üretiminde Üretici Uygulamaları ile Yayım Şubesi Önerileri ve Araştırma Bulgularının Karşılaştırmalı Analizi. Akdeniz Üniversitesi Bilimsel Araştırma Projeleri Koordinasyon Birimi tarafindan desteklenmiş proje raporu (yayımlanmamış), Antalya.

Özçatalbaş O, Ünlü T (2018) The Anaysis of Information Sources Used by Pomegranate Producers in Antalya Province of Turkey. Mediterranean Agricultural Sciences 31(1): 45-48.

Özkan B (2000) Antalya İlinde Sera Sebzeciliğinde Kadın Üreticilerin Rolü. Akdeniz Üniversitesi Ziraat Fakültesi Dergisi 13(2): 133-143.

Soysal M (1998) Köy Sosyolojisi. Çukurova Üniversitesi Ziraat Fakültesi Ders Kitapları Yayın No: A-66, Genel Yayın No: 211, Adana.

Taşdan K, Emeksiz F (2003) Türkiye'de Mısır Üretim, Tüketim ve Dış Ticareti. Çukurova Üniversitesi Ziraat Fakültesi Dergisi 18(3): 97104.

TMO (2017) Toprak Mahsulleri Ofisi verilerinden derlenmiştir, Ankara.

Torun E (2011) Organik Tarımda Çiftçilerin Bilgi Kaynakları (Kocaeli İli Kartepe İlçesi Örneği). KSÜ Doğa Bilimleri Dergisi 14(4): 5362.

TÜIK (2017) Türkiye İstatistik Kurumu verilerinden derlenmiștir, Ankara.

Yalçın M, Boz İ (2007) Kumluca İlçesinde Seralarda Üreticilerin Kullandıkları Bilgi Kaynakları, Bahçe Dergisi 36(1-2): 1-10. 
Yamane T (2001) Temel Örnekleme Yöntemleri.(Cev: Esin A, Aydın C, Bakır MA, Gürbüzsel E). Literatür Yayınları, İstanbul, s. 509.

Yılmaz H, Demircan V, Gül M (2009) Üreticilerin Kimyasal Gübre Kullanımında Bilgi Kaynaklarının Belirlenmesi ve Tarımsal Yayım Açısından Değerlendirilmesi. Süleyman Demirel Üniversitesi Ziraat Fakültesi Dergisi 4(1): 31-44.
Yücer A, Demirtas M, Altun A, Kan M, Celik A, Kalanlar, S (2015) Türkiye'de Tarım Arazilerinin Bölünmesinin Önlenmesine Yönelik Bir Araştırma. Tepge Yayın No: 241, ISBN: 978-605-4672-99-8. Ankara. 